\title{
Instruments and Documents Related to the EU acquis
}

\section{Treaties}

Accord conclu entre le Conseil de l'Union Européenne et la Republique d'Islande et le Royaume de Norvège sur l'etablissement des droits et obligations entre I'Irlande et le Royaume-Uni de Grande-Bretagne et d'Irlande du Nord, d'une part, et la Republique d'Islande et le Royaume de Norvège, d'autre part, dans les domaines de l'acquis de Schengen qui s'appliquent à ces Etats, Doc. No. 9551/99 JAI 54.

Agreement between the Governments of the States of the Benelux Economic Union, the Federal Republic of Germany and the French Republic on the Gradual Abolition of Checks at their Common Borders, 14 June 1985.

Agreement concluded by the Council of the European Union and the Republic of Iceland and the Kingdom of Norway concerning the latter's association with the implementation, application and development of the Schengen acquis, 17 May 1999.

Convention applying the Schengen Agreement of 14 June 1985 between the Governments of the States of the Benelux Economic Union, the Federal Republic of Germany and the French Republic on the Gradual Abolition of Checks at their Common Borders, 19 June 1990.

Convention Determining the State Responsible for Examining Applications for Asylum Lodged in One of the Member States of the Community, Dublin, 15 June 1990, OJ (1997) C 254/1. 


\section{INSTRUMENTS AND DOCUMENTS}

Co-operation Agreement between the Kingdom of Belgium, the French Republic, the Federal Republic of Germany, the Grand Duchy of Luxembourg, the Kingdom of the Netherlands, the Italian Republic, the Kingdom of Spain, the Portuguese Republic, the Hellenic Republic, the Republic of Austria, the Kingdom of Denmark, the Republic of Finland, the Kingdom of Sweden, Contracting Parties to the Schengen Agreement and the Schengen Convention, and the Republic of Iceland and the Kingdom of Norway on the abolition of controls on persons at their common borders, 19 December 1996.

Final Act, Political Declaration by the Governments of the Member States on the Free Movement of Persons, annexed to the Single European Act, OJ (1987) L 169/26.

Protocol integrating the Schengen acquis into the framework of the European Union, annexed to the Treaty on European Union and to the Treaty establishing the European Community, 6 October 1997, Doc. No. CONF 4007/97, TA/P/en 5.

Protocol on Asylum for Nationals of Member States of the European Union, annexed to the Treaty on European Union and to the Treaty establishing the European Community, 6 October 1997, Doc. No. CONF 4007/97, TA/P/en 24.

Protocol on the Position of Denmark, annexed to the Treaty on European Union and to the Treaty establishing the European Community, 6 October 1997, Doc. No. CONF 4007/97, TA/P/en 19.

Protocol on the Position of the United Kingdom and Ireland, annexed to the Treaty on European Union and to the Treaty establishing the European Community, 6 October 1997, Doc. No. CONF 4007/97, TA/P/en 15.

Protokoll zu den Konsequenzen des Inkrafttretens des Dubliner Übereinkommens für einige Bestimmungen des Durchführungsübereinkommens zum Schengener Übereinkommen, Bonn, 26 April 1994, BGBI II 1995. 


\section{INSTRUMENTS AND DOCUMENTS}

\section{Other Instruments and Documents}

Action Plan of the Council and the Commission on how best to implement the provisions of the Treaty of Amsterdam establishing an area of freedom, security and justice, 7 December 1998, Council of the European Union, Doc. No. 13844/98. OJ (1999) C 19/1.

Agenda 2000: For a stronger and wider Europe, 15 July 1997, European Commission, COM (97) 2000 final/1.

Amended proposal for a Joint Action concerning temporary protection of displaced persons (presented by the Commission pursuant to Article 189a(2) of the EC Treaty), 27 August 1998, European Commission, $\operatorname{COM}(1998) 372$ final/2, OJ (1998) C 268.

Circulation and confidentiality of joint reports on the situation in certain third countries, 20 June 1994, Council of the European Union, OJ (1996) $274 / 43$

Committee set up by Article 18 of the Dublin Convention, Dublin ConventionStatistical data on the application of the Convention from 1 January to 31 March 1998, 25 September 1998, Doc. No. DUBLIN CONV 2407/1/98.

Committee set up by Article 18 of the Dublin Convention, Dublin ConventionStatistical data on the application of the Convention from 1 July to 30 September 1998, 6 January 1999, Doc. No. DUBLIN CONV 2415/1/98.

Common Consular Instruction to the Diplomatic Missions and the Consular Posts of the Contracting Parties to the Schengen Convention, which are Headed by Career Consular Officers with its Annexes, not available in OJ.

Communication from the Commission to the Council on Immigration and Asylum Policies, 23 February 1994, European Commission, COM (94) 23 final.

Completing the Internal Market. White Paper from the Commission to the European Council, European Commission, $\operatorname{COM}(85) 310$ final.

Conclusions adopted on 30 November 1992 concerning countries in which there is generally no serious risk of persecutions, WGI 1281.

Conclusions adopted on 30 November 1992 on countries in which there is generally no serious risk of persecution, EC Ministers responsible for immigration, WGI 1281.

Conclusions of 30 November 1994 on the organization and development of the Centre for Information, Discussion and Exchange on the Crossing of Frontiers and Immigration (CIREFI), Council of the European Union, OJ (1996) C 274.

Conclusions of 4 March 1996 concerning readmission clauses to be inserted in future mixed agreements, Council of the European Union, Docs No. 4272/96 ASIM 6 and 5457/96 ASIM 37. 


\section{INSTRUMENTS AND DOCUMENTS}

Conclusions of 27 May 1997 concerning the practical implementation of the Dublin Convention, Council of the European Union, Of (1997) C $191 / 27$.

Conséquences de l'entrée en vigueur du traité d'Amsterdam sur les clauses de réadmission dans les accords communautaires et dans les accords entre la Communauté européenne, ses Etats membres et des pays tiers (accords mixtes)-Adoption d'une décision du Conseil, adopted on 2 December 1999. Neither an English-language version, nor the document number was available at the time of writing.

Council Decision of 26 May 1997 on the exchange of information concerning assistance for the voluntary repatriation of third-country nationals, OJ (1997) L 147/3.

Council Recommendation of 4 March 1996 relating to local consular cooperation regarding visas, OJ (1997) C 80/23.

Council Regulation (EC) No. 1683/95, laying down a uniform format for visas, 29 May 1995, OJ (1995) L 164/1.

Council Regulation (EC) No. 2317/95 determining the third countries whose nationals must be in possession of visas when crossing the external borders of the Member States, 25 September 1995, OJ (1995) L 234/13.

Council Regulation (EC) No. 574/99 determining the third countries whose nationals must be in possession of visas when crossing the external borders of the Member States, 12 March 1999, OJ (1999) L 72/2.

Council Regulation (EC) No. 1260/1999 laying down general provisions on the Structural Funds, 21 June 1999, oJ (1999) L 161/1.

Council Regulation determining obligations as between the Member States for the readmission of third-country nationals, 7 December 1999, OJ (1999) C 353/6.

Decision du Conseil relative à la conclusion de l'accord avec la République d'Islande et le Royaume de Norvège sur l'etablissement des drotis et obligations entre I'Irlande et le Royaume-Uni de Grande-Bretagne et d'Irlande du Nord, d'une part, et la République d'Islande et le Royaume de Norvège, d'autre part, dans les domaines de l'acquis de Schengen qui s'appliquent à ces Etats, 25 June 1999, Doc. No. 9357/99 JAI 50.

Decision of 11 June 1992 setting up the CIREA (Centre for Information, Discussion and Exchange on Asylum), WGI 1107.

Decision of 30 November and 1 December 1992 to establish a Centre for Information, Discussion and Exchange on the Crossing of Frontiers and Immigration (CIREFI), EC Ministers responsible for immigration.

Decision of 6 December 1993 adopting the Council's Rules of Procedure, Council of the European Union, OJ 93/662/EC. 
Decision 2/94, Accession by the Community to the European Convention for the Protection of Human Rights and Fundamental Freedoms, [1996] ECR I1759.

Decision on Alert and Emergency Procedure for Burden-Sharing with Regard to the Admission and Residence of Displaced Persons on a Temporary Basis, OJ (1996) L 063/10.

Decision of 16 December 1996 on monitoring the implementation of instruments adopted by the Council concerning illegal immigration, readmission, the unlawful employment of third country nationals and cooperation in the implementation of expulsion orders, OJ (1996) L 342/5.

Decision of 26 May 1997 on the exchange of information concerning assistance for the voluntary repatriation of third-country nationals, Council of the European Union, OJ (1997) L 147/3.

Decision 1/97 of 9 September 1997 concerning provisions for the implementation of the Dublin Convention, OJ (1997) L 281/1.

Decision 2/97 of 9 September 1997 establishing the Rules of Procedure of the Committee set up by Article 18 of the Dublin Convention, OJ (1997) L 291/26.

Decision $1 / 98$ of 19 June 1998 of the Article 18 Committee of the Dublin Convention, concerning provisions for the implementation of the Convention, OJ (1998) L 196/49.

Decision of the Executive Committee of 16 December 1998 on coordinated deployment of document advisers, not available in $0 \mathrm{~J}$.

Decision 1/99 of the EU/Iceland and Norway Mixed Committee established by the agreement concluded by the Council of the European Union and the Republic of Iceland and the Kingdom of Norway concerning the latter's association in the implementation, application and development of the Schengen acquis of 29 June 1999 adopting its Rules of Procedure, 29 June 1999, OJ (1999) C 211.

Draft list of the 'acquis' of the Union and of its Member States in the field of Justice and Home Affairs, 20 March 1998, Council of the European Union, Doc. No. 6437/98 REV 3.

Draft Joint Action concerning temporary protection of displaced persons, European Council, 16 February 1999, Doc. No. 5682/1/99 REV1, Art. 3 (3) (a).

Draft Joint Action of the Council on airport transit arrangements, 16 July 1998, not published in OJ yet.

EC Ministers Resolution of 30 November-1 December 1992 on a Harmonized Approach to Questions Concerning Host Third Countries, WGI 1283.

EC Ministers Resolutions of 30 November-1 December 1992 on Manifestly Unfounded Applications for Asylum, WGI 1282 REV 1. 


\section{INSTRUMENTS AND DOCUMENTS}

Explanatory Memorandum to the Proposal to the Council for a Joint Action adopted by the Council on the basis of Article K.3 2 (b) of the Treaty on European Union concerning Temporary Protection of Displaced Persons, 4 March 1997, European Commission.

General Declaration on Articles 13 to 19 of the Single European Act. Annexed to the Final Act of the Single European Act, OJ (1987) L 169/25.

Guidelines for a European Migration Strategy, 1 June 1999, Council of the European Union, Doc. No. 8815/99 ASIM 23.

Guidelines for joint reports on certain third countries, 20 June 1994, Council of the European Union, OJ (1996) C 274.

Joint Action of 4 March 1996 adopted by the Council on the basis of Article K.3 of the EU Treaty, on airport transit arrangements, Council of the European Union, OJ (1996) L 63/8.

Joint Action of 22 July 1997 adopted by the Council on the basis of Article K.3 of the Treaty on European Union concerning the financing of specific projects in favour of asylum-seekers and refugees, OJ (1997) L 205/5.

Joint Action of 22 July 1997 adopted by the Council on the basis of Article K.3 of the Treaty on European Union concerning the financing of specific projects in favour of displaced persons who have found temporary protection in the Member States and asylum-seekers, OJ (1997) L 205/3.

Joint Action of 27 March 1998 adopted by the Council on the basis of Article K.3 of the Treaty on European Union, concerning the financing of specific projects in favour of asylum-seekers and refugees, OJ (1998) L 138/8.

Joint Action of 27 March 1998 adopted by the Council on the basis of Article K.3 of the Treaty on European Union, concerning the financing of specific projects in favour of displaced persons who have found temporary protection in the Member States and asylum-seekers, OJ (1998) L $138 / 6$.

Joint Action of 29 June 1998 adopted by the Council on the basis of Article K.3 of the Treaty on European Union, establishing a mechanism for collective evaluation of the enactment, application and effective implementation by the applicant countries of the acquis of the European Union in the field of Justice and Home Affairs, Council of the European Union, OJ (1998) L 191.

Joint Action of 26 April 1999 adopted by the Council on the basis of Article K.3 of the Treaty on European Union, establishing projects and measures to provide practical support in relation to the reception and voluntary repatriation of refugees, displaced persons and asylum seekers, including emergency assistance to persons who have fled as a result of recent events in Kosovo, OJ (1999) L 114/2. 
Joint Position Defined by the Council on the basis of Article K.3 of the Treaty on European Union on the harmonized application of the definition of the term 'Refugee' in Article 1 of the Geneva Convention of 28 July 1951 relating to the status of refugees, OJ (1996) L 63/2.

Joint Position of 25 October 1996 defined by the Council on the basis of Article K.3 (2) (a) of the Treaty on European Union, on pre-frontier assistance and training assignments, Council of the European Union, OJ (1996) L $281 / 1$.

Legislative Resolution embodying Parliament's opinion on the proposal to the Council for a Joint Action based on Article K.3 (2) (b) of the Treaty on European Union concerning temporary protection of displaced persons, 23 October 1997, European Parliament, (COM(97)0093 - C4-0247/97 97/0081 (CNS)), A4-0284/97.

Monitoring the implementation of instruments adopted concerning asylumSummary report of the Member States' replies to the questionnaire launched in 1997, Council of the European Union, 17 July 1998, Doc. No. 8886/98 ASIM 139.

Note by the Presidency, Temporary Protection of displaced persons and solidarity in the admission and residence of such persons in the EU, 29 January 1999, Council of the European Union, Doc. No. 5645/99.

Note by the Presidency to the K. 4 Committee, 'A Strategy for Migration and Asylum Policies', Doc. No. ASIM 170 (1 July 1998).

Note by the Presidency to the Asylum Working Party, Practical application of the principle of solidarity in burden-sharing with regard to the admission and residence of displaced persons, 31 March 1999, Council of the European Union, Doc. No. 7157/99.

Note from the Danish Delegation to the Asylum and Migration Working Parties, Subsidiary Protection, 17 March 1997, Council of the European Union, Doc. No. 6764/97, ASIM 52.

Note from the Presidency, Draft Joint Action concerning temporary protection of displaced persons, Draft Joint Action concerning solidarity in the admission and residence of beneficiaries of the temporary protection of displaced persons, 9 November 1998, Council of the European Union, Doc. No. $12617 / 98$.

Note from the Presidency to the Asylum Working Party, Subsidiary Protection, 23 February 1999, Council of the European Union, Doc. No. 6246/99 ASILE 7.

Note from the Presidency to the K.4 Committee, Strategy paper on migration and asylum, 1 July 1998, Council of the European Union, Doc. No. 9809/98.

Presidency Conclusions, 12 December 1997, Luxembourg European Council, Doc. No. SN 400/97. 


\section{INSTRUMENTS AND DOCUMENTS}

Proposal for a Council Regulation (EC) concerning the establishment of 'Eurodac' for the comparison of the fingerprints of applicants for asylum and certain other aliens, European Commission, 1999/05/26, COM/99/0260 final-CNS 99/0116.

Proposal for a Council Decision creating a European Refugee Fund, 14 December 1999, COM (1999) 686.

Proposal for a Council Regulation listing the third countries whose nationals must be in possession of visas when crossing the external borders and those whose nationals are exempt from that requirement, not available in OJ.

Proposal for a decision based on Article $\mathrm{K}: 3$ of the Treaty on European Union establishing the Convention on the crossing of the External frontiers of the Member States, 10 December 1993, European Commission, $\operatorname{COM}(93) 684$ final.

Proposal for a Joint Action concerning solidarity in admission and residence of beneficiaries of the temporary protection of displaced persons (presented by the Commission pursuant to paragraph 2 (b) of Article K3 of the EU Treaty), 27 August 1998, European Commission, COM(1998) 372 final $/ 2$, OJ (1998) C 268.

Proposal to the Council for a Joint Action based on Article K.3 2 (b) of the Treaty of European Union concerning Temporary Protection of Displaced Persons, 4 April 1997, European Commission, OJ (1997) C 106/13.

Recommendation of 30 November 1992 regarding practices followed by Member States on expulsion, WGI 1266.

Recommendation of 30 November 1992 regarding transit for the purposes of expulsion, WGI 1266.

Recommendation of 1 June 1993 concerning checks on and expulsion of thirdcountry nationals residing or working without authorization, WGI 1516.

Recommendation of 30 November 1994 concerning a specimen bilateral readmission agreement between a Member State of the European Union and a third country, OJ (1996) C 274/20.

Recommendation of 30 November 1994 concerning the adoption of a standard travel document for the removal/expulsion of third-country foreign nationals, OJ (1996) C 274/18.

Recommendation of 24 July 1995 on the guiding principles to be followed in drawing up protocols on the implementation of readmission agreements, OJ (1996) C 274/25.

Recommendation of 22 December 1995 of concerted action and cooperation in carrying out expulsion measures, OJ (1996) C 5/3.

Recommendation of 22 December 1995 on harmonizing means of combating illegal immigration and illegal employment and improving the relevant means of control, OJ (1996) C 5/1. 
Resolution on Burden-sharing with Regard to Admission and Residence of Displaced Persons on a Temporary Basis, adopted on 25 September 1995, Council of the European Union, OJ (1995) C 262/1.

Resolution on the General Principles of a European Refugee Policy, adopted 19 January 1994, Doc. No. A3-0402/93, OJ (1994) C 044/106.

Resolution on the Harmonization within the European Community of Asylum Law and Policies, adopted 15 November 1992, European Parliament, Doc. No. A3-0337/92.

Resolution on Minimum Guarantees for Asylum Procedures, adopted 20 June 1995, Council of the European Union, OJ (1996) C 274/13.

Resolution on unaccompanied minors who are nationals of third countries, adopted on 26 June 1997, OJ (1997) C 221/23.

Rules of Procedure of the Executive Committee established pursuant to Title VII of the Agreement implementing the Schengen Agreement, 18 October 1993, Schengen Executive Committee.

Study on international instruments relevant to subsidiary protection, 13 July 1998, Council of the European Union, Doc. No. 10175/98 ASIM 178.

Summary of replies concerning the national instruments of protection falling outside the scope of the Geneva Convention-Subsidiary protection, European Council, 6 January 1998, Doc. No. 13667/97 ASIM 267. 